\title{
The Manifestation of Gender Peculiarities in Political Discourse
}

\author{
Ruzanna Arustamyan \\ Yerevan State University
}

\begin{abstract}
The article is devoted to the description of gender peculiarities in political discourse. The differences of male and female speeches aim to determine the degree of effectiveness of the impact of gendered approaches in political communication on male and female audiences. We may observe obvious differences between male and female speeches. It is conditioned by biological differences and social roles and stereotypes fixed in the society. Sometimes female politicians tend to imitate male speech behavior in order to defend their positions and the right to participate in the political life of their country.
\end{abstract}

Key words: gender, political discourse, male and female languages, communicative behaviour.

\section{Introduction}

Individual qualities of people are manifested not only in behaviour, lifestyle, but also in speech. People use language for many different reasons. It is used as a method to express feelings or to persuade people and very importantly, it is a part of our self-expression. Nowadays the issue of gender research has become prominent in many spheres such as in psychology, sociology, philosophy, political science and linguistics. In majority of human societies, political power has been a masculine domain. In democratic societies, once women achieved the vote the next debate quickly centered on their "proper role" relative to political power. All over the world, the debate about gender and political power continues (Galliano 2003:321). Gender equality in political power and resources of industrialized democracies has grown tremendously in the past fifty years - more women are running for and being elected to national parliaments than ever before. Virginia Sapiro suggests that most studies of male and female languages reveal women as considerably less influential than men are. (Sapiro 1983:115) However, our research suggests that nowadays women's role in political activity becomes increasingly more important and deserves higher evaluation and attention.

Gender aspect is particularly an interesting sphere of investigation within the field of linguistics - the main focus is on the language differences between men and women. In modern linguistics one of the prior goals in the investigation of political discourse is the study of communicative behaviour as an integral component describing a political leader's activity in professional spheres. According to I. Sternin "verbal behaviour" is the set of norms and traditions of people, communication, age, professional and other groups. (Sternin 2003:106). Gender peculiarities of communicative behaviour of public figures always attract scholars' attention. Gender communicative behaviour is one of the types 
of socially determined communicative behaviour that requires systemic description in political discourse.

\section{The Peculiarities of Male and Female Political Leaders' Speeches}

Speaking generally on the issue of differences between male and female talk, it is worth mentioning that theorists, followers of Robin Lakoff (1975) claim that women's messages are ignored and interrupted because women are taught to "talk like a lady", that is, to use disclaimers ("This may not be right, but..."), "weak" particles ("Dear me", "Goodness", etc.) rather than forceful expletives, and tag questions ("The book was good, wasn't it"), and to express uncertainty rather than assertiveness. When women do not implement these tactics, they may be accused for being unfeminine. However, if they do "talk like a lady", they risk not being taken seriously (Borisoff 1998:10).

Since traditionally, politics is regarded mainly as a sphere of male activity, women do not often play an important role in decision-making processes. The analysis of the speeches of political leaders will give us the opportunity to examine whether any differences are notable in verbal communication when gender is concerned. Thus the language of politicians is endowed with gender approach which implies making a purposeful impact on male and female audiences by using certain characteristic features.

The analysis of speeches of political leaders enables us to assume that there are two major gender approaches,

1. Special features of feminine and masculine speech behaviour which are necessary for creating a certain image. The gender approach is carried out with the help of rapid changes and correction of speech behaviour.

2. Direct appeal to male and female audience - this provides reflection of verbal tactics, as well as different uses of gender stereotypes and metaphors.

The first gender approach may be observed in Hillary Clinton's speeches: she made a very emotional and impressive speech concerning Benghazi crime. She speaks very emotionally which is typical of female speech and shares the sorrow of four American families. She sounds sympathetic and shares their sorrow. For example:

I stood next to President Obama as the Marines carried those flagdraped caskets off the plane at Andrews. I put my arms around the mothers and fathers, sisters and brothers, sons and daughters.

(<http://www.politico.com/gallery/2013/01/hillary-clintons-best-benghazi-hearing-lines/000744-010630.html>)

In general women are more sensitive to the problems and sorrow of close people. By saying "put my arms" Hillary Clinton shows her solidarity with fellow-citizens and makes sure that she thoroughly supports all the victims by mentioning the members of their families: "mothers, fathers, sisters, brothers, sons, daughters". It seems that Clinton tends to unite the pain of the whole nation. As a female politician, she really suffers, cries and shares the sorrow of four American families which is a tragedy for the whole nation. Here the gendered characteristics are displayed on the basis of female 
leader who serves her nation and every single accident may affect and hurt her because she behaves as the mother of the whole nation. The Secretary of State supports them and takes the responsibility of the crime as it is typical for female politicians:

\section{As I have said many times since September 11, I take responsibility. \\ (<http://www.newsy.com/videos/clinton-spars-with-republicans-dur- ing-benghazi-hearing $>$ )}

She takes the responsibility thoroughly and courageously, which means that she is not only a liable politician, but also a good citizen devoted to her own country. The frequent use of the pronoun $\boldsymbol{I}$ also states that the leader separates herself from the others and presents herself as an independent and accomplished politician. As a marker of gender, the frequent use of the pronoun $\boldsymbol{I}$ enables the female politician to establish and strengthen her positions in political areas, as well as to confirm her self-affirmation. This approach is typical of female politicians as they always struggle to prove their status, their right to be considered as equal contenders in the political life of the country.

Here is an example of speech by Hillary Clinton, where she appeals to George Bush to coordinate the actions on Iran nuclear weapon with the US Congress. She states that the main aim of the USA is to stop actions against Iran and adds her view with the following words:

As I have long said and will continue to say, U.S. policy must be clear and unequivocal. We cannot, we should not, we must not permit Iran to build or acquire nuclear weapons. And in dealing with this threat, as I've also said for a long time, no option can be taken off the table.

( $<$ http://www.ontheissues.org/2016/Hillary_Clinton_War_+_Peace.ht m\#Iraq_War>)

The use of modal verbs conveys imperative tone to the speech, the repetition of verbs creates a troubling atmosphere. Furthermore, the syntactic structure of simple sentences promotes an easy perception of communication.

Focusing on Hillary Clinton's linguistic abilities, we must emphasize that her purpose is to preserve her position as a powerful woman. She has the ability to combine the peculiarities of masculine and feminine languages skillfully.

Many political texts reinforce masculine models of communication through aggressive metaphors. Speakers are instructed to "arm" themselves against the other speaker's "argument"; to "win" their point by "waging an attack" on the "weak" points in their "opponent's" logic with a strong "plan of battle". The general stereotypes concerning this theory are very subjective. There are cases when women imitate masculine models of communication, using aggressive and offensive expressions. For example, the debate in South Carolina proves that Clinton is rather aggressive saying:

I personally think that they had ideas but they were bad ideas, they were ideas like privatizing social security, like moving back from a balance 
budget in a surplus of deficit and debt.

$(<\mathrm{http}: / /$ www.youtube.com/watch?v=lgQnTA2jE98>)

She evaluates the ideas of Senator Obama administration "as bad". The main strategy here is the criticism of the opposite candidate by favoring her own candidate. The debate shows that the accepted stereotypes of men's aggressiveness and women's tolerance are not totally acceptable and true.

The concept of interruption is also worth investigating. Debora Borisoff states that the majority of studies proved the evidence that in mixed-gender conversations between couples, colleagues, and adult strangers, men overwhelmingly interrupt women. (Borisoff 1998:40) However, the example of Barack Obama and Hillary Clinton debate shows that this fact is not totally right for all cases. Obama seems to be more tolerant and careful about Clinton's speech. Despite the fact that she traduces and blames him for lying, he never interrupts her.

... it is sometimes difficult to understand what Senator Obama has said, because as soon as he is confronted on it, he says that's not what he meant. The facts are that he has said in a last week, that he really lied.

(<http://www.youtube.com/watch?v=lgQnTA2jE98>)

As far as Clinton is concerned, everything is vice versa - she behaves inappropriately during Obama's speech, she consistently interrupts him trying to defend her positions.

Having analyzed some examples of Hillary Clinton's speeches it becomes clear that she possesses both male and female features. One of these female features is the use of hedges. Robin Lakoff states that "hedges" manifest lack of determination and distrust. (Lakoff R. 2004:83). We can note the frequent usage of "well", "you know", "I mean" and "I think" in Hillary Clinton's speeches.

You know, I'm here tonight as a proud mother, as a proud Democrat... (<http://elections.nytimes.com/2008/president/conventions/videos/200 80826_CLINTON_SPEECH.html>)

And you know - In all of the states, you voted because you wanted a leader who will stand up for the deepest values of our party...

(<http://www.telegraph.co.uk/news/worldnews/democrats/2073000/Hi llary-Clintons-speech-Full-text.html>)

You know, for the past seven years, so many people in this country have felt invisible, like your president didn't even really see you.

(<http://www.telegraph.co.uk/news/worldnews/democrats/2073000/Hi llary-Clintons-speech-Full-text.html $>$ )

You know, tonight, we stand just a few miles from the Statue of Liberty and from the site where the Twin Towers fell and where America rose again.

(<http://www.telegraph.co.uk/news/worldnews/democrats/2073000/Hi llary-Clintons-speech-Full-text.html $>$ ) 
Well, I want what I have always fought for in this whole campaign. I want to end the war in Iraq.

(<http://www.telegraph.co.uk/news/worldnews/democrats/2073000/Hi

llary-Clintons-speech-Full-text.html $>$ )

I mean, I know very well the extensive authority any president has. (<http://www.pbs.org/newshour/bb/politics/jan-june07/clinton_01-

18.html $>$ )

'Well, I am glad you raised that... and I think that...

(<http://www.chathamhouse.org/sites/default/files/public/Chatham $\% 2$

0House/111013Clinton.pdf $>$ )

As for Clinton's intonation, it should be stated intonation and the fact that she usually puts "well" at the beginning of the sentence, which gives her time to think about her response carefully. Sometimes the hedges "well" and "I think" are combined in a sentence and, which endows the sentence with certainty and persuasion.

The following example shows Obama's attitude and speech behavior during his campaign:

We are counting on you to help fix a health care system that's leaving too many Americans sick or bankrupt or both. We are counting on you to bring this planet back from the brink by solving this crisis of global climate change. We are counting on you to help stop a genocide in Darfur that's taking the lives of innocents as we speak here today.

$(<$ http://www.snhu.edu/6885.asp $>)$

On the one hand, the use of the pronoun we allows us to separate Obama from "young' audience of graduates who must be able to make decisions. On the other hand, the leader uses the tactics of criticism implicitly which is expressed by indirect forms of negative assessments of the existing situation in the country and in the world. In the passage above the manipulation of public consciousness due to intentional negative indications can be observed. At the same time there are some hidden capabilities of improving the situation. Obama seems to be saying - "Choose me, and we'll reform everything." Here we can see the gendered aspect of a self-confident male politician who acts like a leader. In contrast to female features, male politicians do not seem to prove their rights to take part in political sphere. Instead, they are in a more privileged position and they only defend their points of views without trying to prove that they have the right to participate in the political life of the country.

The former US Secretary of State Condoleeza Rice also appeals to this approach by changing her gender-specific style. She uses speech behaviour typical of her speech, thus combining the use of both feminine and masculine features. During her trip to Asia, Condoleeza Rice delivered a speech characterized by peculiar male features. At the beginning she mentions the goal of her trip:

"The purpose of my trip is to rally the support of our friends and allies in Northeast Asia for our comprehensive strategy." Then the political 
leader alternately explains the program and substantiates the aim of the visit: "First, we must strengthen our strategic relationships in the region. ... Second, as North Korea scorns the international community, we .... Third, we and our partners must expand defensive measures to counter .... Fourth, we must ensure the continued vitality of the global regime .... Finally, we must remind North Korea that a positive path remains open to it through the six-party talks."

(<http://2001-2009.state.gov/secretary/rm/2006/74047.htm>)

Her speech is constructed very logically and precisely. The sentences are simple and clear. Like Clinton, Rice also unifies the actions with the help of the pronoun we.

Consequently, this part demonstrates that the speech of $\mathrm{C}$. Rice does not contain any emotional tone and language means typical of female speech. Instead, the speech is distinguished with logical structure and sequence.

Applications of gender approaches towards men and women audiences in the language of political figures is carried out by other means. There is a bright example of Tony Blair's speech during General Assembly third Committee of the UN dedicated to Women Institutions. He deliberately constructs his speech in order to be pleasant to the audience and speaks on the issues which concern women, such as family, children, breast cancer, discrimination against women and so on:

... we all share the anxieties of today's world: the fear that our child will be bullied or worse offered drugs in the playground. The worry that children are exposed to too much sex and too much violence too young. The struggle of balancing work and family. ... On our own the majority of us are powerless. Together we can shape our destiny. To become the masters of this change, not its victims, we need an active community.

(<http://webarchive.nationalarchives.gov.uk/20060715135117/number10.gov.uk/page1526>)

The political leader places himself in the position of women, shares their problems and conveys the whole information in emotional and figurative manner.

The US former Secretary of State Madeleine Albright's speeches are constructed on the basis of family gender stereotype:

I will always love and honor my parents and will always respect their decision, for that most painful of choices gave me life a second time. (<http://1997-2001.state.gov/www/statements/970713b.html >)

Devotion and respect towards parents are appreciated by different generations and promote the image of a loving daughter. 


\section{Conclusion}

Thus, the investigation shows that the right choice of gender approach conveys vividness and interest to the politician's language, endorsing its impact on the audience. In some cases the boundaries between masculinity and femininity are erased or manifested implicitly. Sometimes female politicians try to cross these limits - this is conditioned by the fact that female political leaders tend to preserve and defend their positions by imitating masculine manners of speech.

\section{References:}

1. Borisoff, D.; Merrill, L. (1998) The Power to Communicate. Gender Differences as Barriers. Illinois: Waveland Press.

2. Briefing on Upcoming Trip to Asia. Available at: $<$ http://2001-2009.state.gov/secretary/rm/2006/74047.htm $>$ [Accessed June 2014]

3. Grace Galliano (2003) Gender Crossing Boundaries. Kennesaw State University.

4. Robin Tolmach Lakoff, Mary Bucholtz (2004) Language and Woman's Place. New York: Oxford University Press.

5. Virginia Sapiro (1983) The Political Integration of Women: Roles, Socialization, and Politics. Urbana and Chicago: University of Illinois Press

6. Sternin, I.A. (2003) Ocherk angliyskogo kommunikativnogo povedeniya. Voronezh: Izdatelstvo "Istoki".

7. Briefing on Upcoming Trip to Asia. Available at: $<$ http://2001-2009.state.gov/secretary/rm/2006/74047.htm $>$ [Accessed June 2014]

8. Chatham House Prize 2013: In Conversation with Hillary Rodham Clinton. Available at: $<$ http://www.chathamhouse.org/sites/default/files/public/Chatham\%20House/111013 Clinton.pdf $>$ [Accessed January 2014]

9. Clinton spars with Republicans during Benghazi hearing. Available at: $<$ http://www.newsy.com/videos/clinton-spars-with-republicans-during-benghazihearing $>$ [Accessed December 2013]

10. Hillary Clinton's best Benghazi hearing lines. Available at: $<$ http://www.politico.com/ gallery/2013/01/hillary-clintons-best-benghazi-hearing-lines/000744-010630.html> [Accessed December 2013]

11. Hillary Clinton on Warand Peace. Available at: <http://www.ontheissues.org/2016/ Hillary_Clinton_War_+_Peace.htm\#Iraq_War> [Accessed in December 2013]

12. Hillary Clinton's remarks at a rally on Tuesday in New York City. Available at: $<$ http://www.telegraph.co.uk/news/worldnews/democrats/2073000/Hillary-Clintonsspeech-Full-text.html $>$ [Accessed December 2013]

13. Hillary Rodham Clinton's Speech at the Democratic National Convention. Available at: $<$ http://elections.nytimes.com/2008/president/conventions/videos/20080826_CLINTON_SPEECH.html $>$ [Accessed December 2013]

14. Obama and Clinton Heated Exchange in South Carolina Debate. Available at: $<$ http://www.youtube.com/watch?v=lgQnTA2jE98> [Accessed January 2014] 
15. Secretary of State Madeleine K. Albright Remarks at Jewish Museum Prague. Available at: <http://1997-2001.state.gov/www/statements/970713b.html $>$ [Accessed January 2014]

16. Sen. Barack Obama's Commencement Remarks. Available at: $<$ http://www.snhu.edu/ 6885.asp.> [Accessed January 2014]

17. Senator Clinton calls for cap on U.S. troops in Iraq. Available at: $<$ http://www.pbs.org /newshour/bb/politics/jan-june07/clinton_01-18.html> [Accessed January 2014]

18. Women's Institutes' Triennial General Meeting. Available at: $<$ http://webarchive. nationalarchives.gov.uk/20060715135117/number10.gov.uk/page1526> [Accessed January 2013]

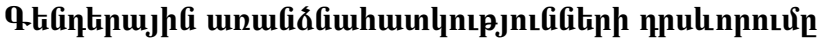 punupuludi lununıjpnıx}

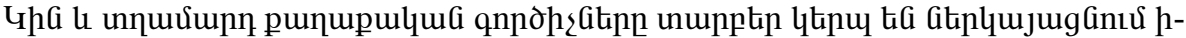

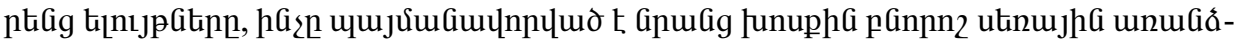

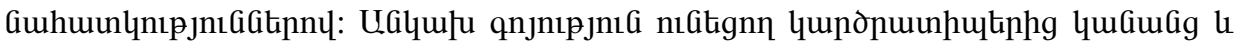

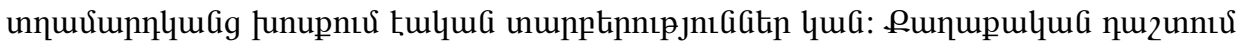

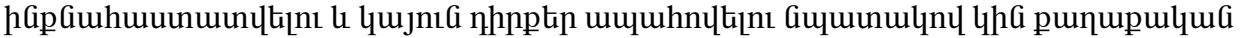

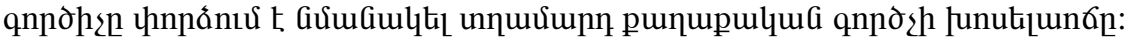

\section{Проявление геднерньх особенностей в политическом дискурсе}

Женщины и мужчины политики по-разному строят свою речь во время выступлений. Это обусловлено половыми различиями мужчин и женщин. Несмотря на существующие стереотипы, которые характеризуют речевые действия в речевой деятельности обоих полов, есть явные различия. Женщины политики часто пытаются имитировать мужское речевое поведение с целью защитить себя, установить собственные взгляды и право участвовать в политической жизни страны. 